\title{
Prophetic Theology in Black Theology, with special REFERENCE TO THE KAIROS DOCUMENT
}

Author:
Vuyani S. Vellem ${ }^{1,2}$

Affiliations:

${ }^{1}$ Department of Science of Religion and Missiology,

University of Pretoria,

South Africa

${ }^{2}$ South African Council of Churches, Marshall Town, South Africa

\section{Correspondence to:}

Vuyani Vellem

email:

vido@executivemail.co.za

Postal address:

PO Box 62098, Marshall

Town 2107, South Africa

\section{Keywords:}

Confession; crisis;

mokhukhu; political praxis; vuvuzela

\section{Dates:}

Received: 13 Feb. 2010

Accepted: 06 July 2010

Published: 08 Oct. 2010

How to cite this article: Vellem, V.S., 2010,

'Prophetic Theology in Black Theology, with special reference to the Kairos document', HTS Teologiese Studies/ Theological Studies 66(1), Art. \#800, 6 pages. DOI: 10.4102/hts.v66i1.800

This article is available at: http://www.hts.org.za

Note:

This article was initially presented as a paper at the conference on 'Prophetic witness: An appropriate mode of public discourse in democratic societies?' that was held at the University of Pretoria on 26-27 October 2009.

(C) 2010. The Authors. Licensee: OpenJournals Publishing. This work is licensed under the Creative Commons Attribution License.

\section{ABSTRACT}

The 'Protest' and 'Confessing' Models in the streams of Black Theology of liberation provide a creative link between the Prophetic Theology in the Kairos document $(K D)$ and the Black Theology of liberation. Launched in a distinct moment of history - an 'opportune moment' the $K D$ propagated the best responses among some and the worst among others as a rapturous critique of State and Church theologies. In this article, I argued that the $K D$, which remains a version of liberation theology par excellence, offers a methodology that is still appropriate to our democratisation processes in South Africa. The $K D$ is the product of a theology that did not only expand the contours of traditional theology, but also understood confession as a political praxis. Thus, the interest of the poor should still mitigate forth-telling in our democratic vision in dialogue inspired by the alluring prophetic vision of an alternative community based on the principles of the reign of God.

\section{INTRODUCTION}

Finding the rubric of Prophetic theology in the Black Theology of liberation, with special reference to the Kairos document (KD) seems to be obvious if Kairos theology is liberation theology, as many commentators have argued. In this article, I engage in this conversation to delineate the question of the integral relationship between Black Theology, Prophetic Theology and the KD in the new South African context. A little historical background to the development of the $K D$ is given to sketch how the project of Prophetic Theology has been integrated into liberation theology in South Africa. To achieve this goal, I begin with a short background of the $K D$, followed by a brief synopsis of the relationship between Prophetic Theology and Kairos theology. I conclude the article by demonstrating what the appropriation and the relevance of Prophetic Theology in South Africa could be today.

\section{THE KAIROS DOCUMENT}

The KD (1986) opens its first chapter with the following words:

The time has come. The moment of truth has arrived. South Africa has been plunged into a crisis that is shaking the foundations and there is every indication that the crisis has only just begun and that it will deepen and become even more threatening in the months to come. It is the KAIROS or moment of truth not only for apartheid but also for the Church.

(Kairos Document 1986:1)

Kairos is a Greek word that connotes a particular kind of time, that is, an opportune moment, or a crisis, as the quotation above suggests. It is a moment that is pre-eminently distinct to mark a different period from another period or epoch. ${ }^{1}$ Kairos does not mean the same thing as chronos, another Greek word for time, which simply designates a chronology or succession of moments of time. Among the key words that come to mind when one goes back to the Kairos moment in South Africa is the word 'crisis.' The KD was scripted in a time of crisis, dubbed in those days as an opportune moment, a challenge of the times, but simultaneously an opportunity. The KD (1986:1) says, 'A crisis is a judgement that brings out the best in some people and the worst in others'.

Launched on 28th September 1986, the KD prompted a variety of comments and views across South Africa. To some quarters of the South African church it was like an 'irritating', 'vexatious,' 'unconventional' vuvuzela sound that invaded the Confederations Cup in South Africa in 2009. ${ }^{2}$ It was a sound of a voice that showed how the church was divided in its response to the apartheid regime. Remember that in the argument for the use of vuvuzelas at the Confederations Cup, others argued that a vuvuzela is a welcome, home-grown instrument used by soccer lovers to inspire their teams. The rupture of the $K D$ was more than this. It was probably like a 'volcanic' irruption protruding out of the township belly during the 1985 State of Emergency in South Africa. The crisis of death was intensifying as more and more people were detained and killed. Townships had become ungovernable sites of the struggle

1.For another definition of kairos see Nolan (1988:183). He added in his rendition that: 'The kairos or moment of truth has come because the day of the liberation is near' because, in his view, kairos should be linked to the eschatological dimension of time. Israel Batista (1995:34) needs to be mentioned too when he says '"Kairos" originally means the "decisive thing", the "essential point"' Batista also adds that kairos is a time that acquires a unified alignment towards a goal set by God.

2 Imagine the controversy on the use of the vuvuzela in the Confederations Cup in South Africa! I find the image of a vuvuzela quite appealing for a number of reasons. This is a horn blown in South African stadia by soccer fans. Some dislike it, while the fans find its 'cacophonous' sound an inspiration to support their team. During the Confederations Cup in South Africa, a public debate on the use of the vuvuzela erupted and views were expressed for and against it. It is also important to recognise that in some churches, particularly Black African churches, vuvuzelas are used in singing and dancing. Today in South Africa, the vuvuzela image has become a public lexicon that is used even to market products in newspapers, cf. the phrase 'come blow your vuvuzela' in an advert in the Mail and Guardian (29 January-04 February 2010:14). This image is nonetheless employed to convey the 'noisy', 'controversial' theological altercations and debates that ensued after the launch of the $K D$, yet the blowing sounds of the $K D$ remained an inspiring theological paradigm that spread through the whole world. 
as they revolted against the tyranny and bigotry of the apartheid state. South Africa was indeed plunged into a crisis in which the state resorted to massive use of power, with almost every township having become a site of incursion by legions of the South African apartheid military forces.

The country's foundations were shaken by a massive popular 'tsunami' of a theology arising from the dusty streets of the township. It was a clearly distinguishable spirit of the time - 'a time between times' to employ Khabela's phrase. ${ }^{3}$ The use of these images is deliberately intended to paint a picture of an indescribable moment of a change of time and a change of history in South Africa when people resorted to whatever means they had to convey their deepest feelings. These images also carry the contradictions of that moment, as much as they reflect the current contradictions in our country today and are a repugnant spectacle of the violence and crime against millions of South Africans in the 1980s. John de Gruchy (1991) says,

In the same way, the point of departure for the authors of the Kairos Document in South Africa is a decisive break with the colonial and neo-colonial captivity of the churches in southern Africa and with the 'state' or 'church theology' underpinning it.

(De Gruchy 1991:38)

The launch of the $K D$, we should imagine, was like a decisive blow of a home-grown liberation theology, a decisive irruption of a voice in the burning townships and a powerful wave that ruptured the approach of doing of theology in South Africa from the colonial and neo-colonial assumptions that captivated the churches in South Africa for centuries.

The $K D$ delineated three models of theology: State Theology, Church Theology and Prophetic Theology. State Theology was a model of theology that justified the status quo. It was a theology that sought to legitimise an illegitimate state for it was a theology of the apartheid state that canonised racism, capitalism and a totalitarian state against the Black people of South Africa. To achieve this end, State Theology misused theological concepts and biblical texts, such as Romans 13:1-7. Some will remember what was then called the 'Doctrine of common purpose', which empowered the state to incarcerate people without trial who were believed to have pursued the agenda of undermining the state. Under this regime, even the meaning of a meeting assumed a different definition. More than two people for example, found standing at any corner of the street in the township would easily be detained, because meetings or gatherings were against the law of the apartheid regime. Law and order had become an aberration, which resulted in the ubiquitous presence of legions of the military force hording and hovering over almost every space of life in the township.

The concept of law and order was a lived paradox as it was used to support the unjust and discriminatory laws of apartheid. According to the KD (1986:3), State Theology was prone to appealing to the conscience of the nation to uphold and respect 'the organized and institutionalized disorder of oppression'. The label 'communist' was used against anyone who opposed the state, such as Desmond Tutu. State Theology, while claiming to be apolitical, was, on the contrary, virulently committed to the political agenda of the apartheid state. De Gruchy (1991:76-77) interprets State Theology as a critique of Afrikaner Calvinism, while Church Theology, to which I now turn, was as an indictment against the English-speaking churches in South Africa. Church Theology was a form of a 'middle axiom' approach to the theological questions of the day. In regard to Church Theology, the KD (1986) says:

We have analyzed the statements that are made from time to time by the so-called 'English-speaking' Churches. We have looked at what Church leaders tend to say in their speeches and press

3.The phrase is taken from Gideon Khabela's title of his sermon at the 1993 General Assembly of the then Reformed Presbyterian Church in Southern Africa, now the Uniting Presbyterian Church in Southern Africa. statements about the apartheid regime and the present crisis. These we have chosen to call 'Church Theology.' We are well aware of the fact that this theology does not express the faith of the majority of Christians in South Africa today who form greater part of most of our Churches ... In a limited, guarded and cautious way this theology is critical of apartheid. Its criticism however, is superficial and counterproductive because instead of engaging in an in-depth analysis of the signs of our times, it relies upon a few stock of ideas derived from Christian tradition and then uncritically and repeatedly applies them to our situation.

(Kairos Document 1986:4)

The crux of the criticism of this theology is crystal clear in the quotation above. It was clearly a form of theology in which the criticism of the state was superficial, guarded, exaggeratedly cautious and ultimately impertinent to 'the signs of the times' from the perspective of the suffering. Church Theology was bourgeois, liberal and not zealously committed to dealing with structural challenges in society that demanded social and ecclesiological transformation. Church Theology did not express the faith of the majority of Christians in South Africa, but it was characterised by numerous aspersions it cast against those perceived to be outside of the norms and canons of 'mainstream' traditional theology. Its exponents evidently perceived the KD not as 'proper' theology. Albert Nolan (1988), for example, wrote:

One of the frequent criticisms of the Kairos Document, mostly made by white Christians, is that it was too emotional. How could a Christian document express so much anger and indignation? One can only wonder what such critics make of the anger and indignation of the prophets and of Jesus himself.

(Nolan 1988:105)

We should read in these sentiments above the prejudice and arrogance of Enlightenment rationality against the emotions. Often, emotions are discarded as irrational by proponents of Enlightenment rationality. The criticism that the $K D$ was too emotional simply attempts to portray the $K D$ as an irrational expression of anger and, ipso facto, illogical as a theological document that should not be taken seriously. That we need to be always cautious about our emotions and be objective, that is, 'intelligent' when scrutinising or examining matters is a logic borne out of this prejudice, which, itself, is an abstraction of the very essence of rationality. That the $K D$ expressed so much anger prompted false assumptions about the relationship between anger and theology, to which Nolan (1988:n.p.) responded: 'One can only wonder what such critics make of the anger and indignation of the prophets and of Jesus himself.' Indeed, of the English-speaking churches that accepted the criticism of the KD and actually rejected the fundamentals of apartheid theology, few actually found the content of the $K D$ palatable.

The KD debunked some of the theological ideas, such as reconciliation, peace, justice and non-violence, that were central to the discourse of Church Theology. The KD argued that there could be no peace without justice, that there was no place for cheap grace and reconciliation and, lastly, that the choice had to be made between reform and revolution.

According to Khabela (1991:276), issues of reconciliation, justice and non-violence had to be dealt with from the point of view of the oppressed, rather than from a historical and theological perspective that does not take into account the special exigencies of oppression in South Africa. Various campaigns of the 1980s, such as the Mass Democratic Movement, the Standing for the Truth Campaign and other forms of praxis at that time, spoke volumes about a rupture from a dominant logic of the day. For me, the Kairos moment remains the soil in which the current talk of the National Democratic Revolution by the African National Congress must be rooted - a break from the historical and theological perspectives that did not take into account the special exigencies of the masses, their symbols, language and experience. 
The third model of theology in the KD, and perhaps the most crucial for this topic, is Prophetic Theology. According to the $K D$, a Prophetic Theology that was clear and unambiguous was the route to take in that South African kairos. De Gruchy (1991:35) actually suggests that the $K D$ is the most powerful expression of Prophetic Theology. Khabela's (1991) statement, though, is much more telling for us:

Produced by a group of church ministers, black theologians and other church people (mostly untrained theologians) the Kairos document addressed the intensifying crisis in the country as more and more people were being killed, maimed and imprisoned, as one township after another revolted against the apartheid regime; and greater numbers of people refused to cooperate with the apartheid system.

(Khabela 1991:275)

I shall not dwell on the Khabela's sentiments above, as I have already spelt them out in this article so far. The fact that the $K D$ was produced by Black theologians, among others, is however, a pivotal assertion we cannot simply overlook for this conversation. ${ }^{4}$ The assertion that Black theologians among others produced the $K D$ clearly makes an important connection between a Black Theology of liberation and the KD.

The KD stated that Prophetic Theology had to be spiritual, pastoral and, above all, prophetic; its contours had to include, inter alia, the following themes:

- social analysis

- critical biblical interpretation to debunk oppression in the Bible

- the tyranny in tradition, i.e. Christian tradition

- a message of hope.

The Black Theology of liberation has distinctly positioned social analysis above philosophy in its methodology and, as such, vehement arguments for the development of a Black hermeneutical approach to the study of the Bible have been made by scholars such as Itumeleng Mosala (1989). There is no need to emphasise that the sustained debate between orthodoxy and praxis that became rife in the Black Theology of liberation and other liberation theologies against the tyranny of tradition attests to the commitment of Black theology to this theme. Indeed, the Black Theology of liberation argues that the experience of the Black masses constitutes the hope in which the message of the gospel of Jesus Christ is embedded. The distinct feature of Prophetic Theology as proposed by the KD was therefore, its logic, namely that the KD espoused a method that focused on structural sin and injustices with the oppressed as a hermeneutical key for radical change. Suffice it to say that the call for Prophetic Theology beckoned the churches to move away from State Theology and Church Theology with haste. With this in mind, it becomes necessary to delve into a brief excavation of the streams of prophetic motif in the Black Theology of liberation.

\section{PROPHETIC THEOLOGY IN THE BLACK THEOLOGY OF LIBERATION}

Black Theology is an intellectual tradition that is intercontinental and seamless in its connection to liberation. One of the descriptions of Black Theology I offer is that it is a cogent response to the internal contradictions of Christian theologies that baptise allegiance to the status quo within the external sociopolitical challenges experienced as painful, violent exclusion and domination by the Black African masses in the country of their birth. The Black Theology of liberation entails that much

4. The ideological differences between a Black Theology of liberation and Liberation theology in South Africa cannot be forgotten. There has been a tendency to give preference to Latin American liberation theology over the Black The to preference to Latin American liberation theology over the Black Theology of 政 seldom made and this can only be explained through the underlying ideological choices. of science, philosophy and religion are ideological constructions intent on protecting the interests of the powerful against the oppressed. In this manner, the Black Theology of liberation challenges forms of power, such as racism, patriarchy, sexism and economic exclusion, which perpetuate the oppression of the poor.

Therefore, as a liberation theology, the goal of Black Theology is to open the horizons of those who suffer vicious oppression and domination in their land of birth. The affinity between colonisation and Christianisation places Black Theology equally as a response to the original exclusion of Black African people in the discourse of God-talk and the construction of the histories and knowledge among the peoples of the earth. There are various streams from which we can weave the prophetic motif into the Black Theology of liberation. These streams are not necessarily unrelated, but simply provide us with prisms though which we can decipher the prophetic roots of the Black Theology of liberation.

The first stream of prophetic discourse in Black Theology can be traced to the earliest critique and resistance by Black Africans against colonisation, designated as the 'Protest Model' by Khabela (1991:304-309). This stream features the well-known era of the African Initiated Churches (AICs), which was characterised by a contest of worldviews between Western Christianity and the African people and saw the rise of the Ethiopian Movement. This era was predominantly nationalistic and socio-political and resonated with the formation of churches and political movements that were led by Black African people. Boesak (2004:10) asserts that the 'Protest Model' of resistance against the hegemonic and dominant forms of White Christianity was prophetic, because the White church was so intertwined with the colonial project that it lacked criticality and a prophetic presence From an American perspective, Cornel West (1993:411) also identifies four streams of prophetic tradition in Black Theology and places the critique of slavery in America as the first tradition of the prophetic instances in the development of Black Theology. This parallel between the South African and American Black Theologies of liberation maintains that resistance against the colonial project, which was intertwined with Christianity, is a prophetic instance from which the roots of a prophetic theology in Black Theology can be traced.

Another stream of the prophetic trajectory in Black Theology, and quite an important one for the thesis of this article, is the 'Confessing Model'. Circumscribed especially by the Sharpeville massacre in 1960, which led to the Cottesloe Conference, the 'Confessing Model' provided a fertile soil for the emergence of a much more systematic account of Black Theology of liberation in South Africa. A confessional critique of institutional racism and its violence was discussed at Cottesloe and declared as a sin against God. The Black Theology of liberation, however, went a little deeper and located its ethos of the confession of the lordship of Christ over all creation within the matrix of the Black Consciousness philosophy notably associated with prominent anti-apartheid activists such as Steve Biko. Thus the 'Protest' and 'Confessing Models' provide streams from which we can decipher prophetic instances in Black Theology. In other words, I argue that the rise of the AICs, the Ethiopian Movement (the 'Protest Model') and the 'Confessing Model' are incarnations of the prophetic tradition in the Black Theology of liberation.

Of course I need to add that the narrative of a prophetic instance in the Black Theology of liberation still has its residual presence in our midst today. The text of the AICs is present through a spectacle of sordid and squalid conditions signified by a mokhukhu (a shelter) on the peripheries of our cities even after the demise of apartheid. A mokhukhu heuristically captures the ecclesiological

5.Some years ago, when I was a pastor in Limpopo Province, I got to know that the word mokhkuku was used to denote the Zion Christian Church (ZCC). In fact at Thune, a village that was one of the Donhill outstations where I was a pastor, there was this 'stros was this 'strcture' 'perceive the image of mok' phuis not intended to denigrate any of the AlCs that use these structures every Sunday as their places of worship. On the contrary, the intention is 
character of most of the AICs, where healing is actually central. To illustrate this point, we only need to remember that the Black Theology of liberation has deeply reflected on the psycho-social dimensions of oppression, which is represented, for most Black people, by a mokhukhu. Yet a mokhuku is like a large 'psychiatric' ward in which institutionalised racism that dented both the self esteem of the oppressor and the oppressed constantly receives healing. It represents the psychosis and paralysis of social life that is a reality, a concrete experience of millions of South Africans who attend church every Sunday in mekhukhu (plural of mokhukhu). A mokhukhu is a residual symbol of a repugnant socio-political malady that links Black Theology to the present challenges of prophetic witness.

The 'Protest Model' is a stream that suggests the indigenous linguistic, symbolic and syntactic forms of faith expression are a prophetic instance against the foreignness of Christianity and its captivity to Constantinian hegemony of ecclesiology, in the same way as the Ethiopian movement is an ecclesio-political response to the racial exclusion of many Black clergy in leadership and the sharing of resources is an impulse of a prophetic tradition in Black Theology. A number of confessions of South African experience that were developed, to disarticulate the logic of White Christianity, such as the Status Confessionis and the Belhar Confession, assert this point. Boesak (2004) paints the picture in this manner:

Understanding the intertwined nature of Christianity, colonialist expansion and white racism, one should therefore not be surprised at the lack of resistance, of critical thinking, of a prophetic presence of the Christian church in society at the time. The church identified wholly with the colonial project and could not conceive of a vision divorced from the vision of the imperial power, whether that vision was expressed by Jan van Riebeeck or Cecil John Rhodes, Willem van der Stel or Lord Charles Somerset. The criminal appropriation of the land, the genocide of the Khoi and the San, the destruction of the African peoples as a whole as well as their cultures, the enslavement of people, indigenous and imported - all this was not only permissible. It was unavoidable and necessary for the colonial project and therefore the will of God.

(Boesak 2004:10-11)

Boesak (2001) expressed the sentiments above in contrast of the prophetic instance in the history of Christianity in South Africa, about which he says:

In the early history of 'Christian' South Africa the prophetic instance, the moment of recognition that the truth of the gospel was crushed to earth and needed to rise again, was created, underdeveloped though it was, not by the institutional church and its theologians, but by the representatives of the missionary societies in South Africa and the African people themselves.

(Boesak 2004:11, emphasis added)

I have appealed to Boesak's sentiments firstly to illustrate that the 'Protest Model' was responding to, that is, the intertwined nature of Christianity, colonialist expansion and White racism. Secondly, the charge that Boesak makes that there was no prophetic presence in the missionary Christianity is crucial. He avers that the prophetic instance came through representatives of the missionary society and the indigenous leaders. This is therefore, a prophetic rupture which streamed into the development of a Black Theology of liberation, not by the institutional church but representatives of missionary societies and the African people. The fact that it was seen as not only permissible to appropriate the land, commit genocide and destroy the African people, but also unavoidable and necessary and, therefore, the will of God to colonise Black people is an indictment against the confessional edifice of White Christianity in South Africa.

(Footnote 5 cont...)

to convey the prophetic nature the symbol of mokhukhu instances in our midst. For many Black people, mokhukhu signifies landlessness, socio-political deprivation, social psychosis and exclusion of millions who also dwell in these structures. It is thus a mine of faith 'assets' that we still need to harness for our understanding of prophetic dimension of theology in South Africa today.
Theology is a contextual theology. According to Van der Water (1998), contextual theologies are virtually no different from Prophetic Theology and their integration is necessary for the development of Prophetic Theology in South Africa. Kairos theology is prophetic in its interpretation of the Gospel. The convergence of contextual theologies and Kairos theology occurs at the point of the experience of crisis by ordinary people and is indicative of how they attempt to reflect on their faith in such crises. The poor constitute their normative context, in which prophetic theology begins, as a conversation with God.

Taking this argument further it becomes relevant to bring in Kalu (2006), who also argues that in Black Theology, confession served as a form of political praxis. If confession is political praxis in Black Theology, then the link between confession and Prophetic Theology at the level of confession could be further elucidated, perhaps by bringing Cone (1982) into the argument. Particularly puzzled at the acceptance, without alteration, of the confession of faith of White denominations by churches that separated from them, Cone (1982:188) argued that such an acceptance did not address the inherent flaws of White liberal thinking about God. Cone (1982) sought to address the flaws about God in the confessional and liberal thinking of White churches when he justified his development of a Black Theology of liberation:

From Barth and others I knew all about the theological dangers of my procedure. Identifying the gospel with historic-political movements was anathema to anyone who bases his theology on divine revelation. But I purposely intended to be proactive in much the same way that Barth was when he rebelled against liberal theology. As Barth had turned liberal theology upside down, I wanted to turn him right-side up with a focus on the black struggle in particular and oppressed people generally.

(Cone 1982:45)

While confession is largely understood as a statement of faith to define 'correct' interpretation and articulation of faith, Cone turned the understanding of confession into political praxis and developed his scheme of Black theology of liberation. There are important observations we must make at this juncture: Cone was influenced by the Barmen declaration and the same Barmen declaration influenced the South African theologians who penned down the $K D$. Furthermore, I have demonstrated that confession is a central motif to the prophetic trajectory in the Bible. What this means is that there are common sources between Cone and the Kairos theologians. Fundamentally, if Cone is representative of a pioneer of the Black Theology of liberation, such a use of common sources by Cone and the Kairos theologians points to shared roots between the Black Theology of liberation and the $K D$. In the same manner, the convergence between the Black Theology of liberation, the KD and Prophetic Theology is established by the motif of confession as political praxis. Indeed, as Christians, we have to declare our vision in our own communities and also in the world for the rediscovery and authentication of our faith. Prophetic Theology derives from this Biblical compulsion of prophecy, that is, the compulsion of the prophetic mandate to be truthful in witness and in unity of faith, rather than in the unity of the structures of the church and the correct articulation of faith. Such a compulsion irrupts from the impulses of the underside of history, beneath the manifest institutional structures of the church and public life.

Indeed, if Cone finds a confession of faith in the Barmen declaration that provided him with a strategy to develop a theology that deconstructs the orthodox notions of confessional theology, then Black Theology is prophetic because it is 'right-side up'; it is a confessional theology that prizes the dimension of political praxis and a comprehensive experience of the powerless Black community to give witness to the ultimate principles of the reign of God and the meaning of life. 


\section{PROPHETIC DISCOURSE IN A DEMOCRATIC SOCIETY}

The question to now briefly answer is whether prophetic theology is still appropriate in our current democratic dispensation in South Africa. Having accorded a greater space in the article thus far to articulating the foundational link between Prophetic Theology, Black Theology of liberation and the KD, it is my understanding that it is not the essence of a Prophetic Theology that should be changed in our new context. Rather, I argue that the appropriation of Prophetic Theology in the context of democracy in South Africa could be redefined in mode, but not essence ${ }^{6}$.

Firstly, the compulsion to give witness and to 'blow'7 our voices in public life simply requires an inspired careful reading of the signs from the point of view of the powerless. Forth-telling, which is an important category of prophetic theology implies a discipline of understanding the situation and analysing it well. The narratives of the poor Black masses, their experience and language of life in millions of mekhkhu, provide the necessary compulsion for us to forth-tell through critical analysis the policies and systems that pervasively undermine the interests of the poor. Secondly, Prophetic Theology offers us the methodological tools to critically engage with the potential foreignness of the democratic system in South Africa.

A distinction between a system of democracy and the vision of democracy that comes closest to the principles of the reign of God always needs to be made, as systems cannot necessarily translate into the substantive promises of democracy. As we speak, there are many systems of democracy in the world, but a system of democracy such as suggests espoused in this country cannot succeed without being mitigated with the worldviews of the majority who were historically marginalised and continue to be poor. It is the task of Prophetic Theology to engage the foundations of democratic polity 'right-side up' as the notion of democracy itself cannot be left unproblematically to benefit the liberal hegemony of the meaning of democracy.

Indeed in the era of 'regime change' in our world today, the undemocratic nature of the dominant and hegemonic neoliberal impulse in politics and in the economy, which continues to widen the gap between the poor and the rich, is that the compulsion to be prophetic is still appropriate in this new context. The Accra Confession is a sound example of how a prophetic voice can be 'blown' 8 in the new situation. The Accra Confession for example says:

16. Speaking from our Reformed Tradition and having read the signs of the times, the general council of the World Alliance of Reformed Churches affirms that global economic justice is essential to the integrity of our faith in God and our discipleship as Christians. We believe that the integrity of our faith is at stake if we remain silent or refuse to act in the face of the current system of neoliberal economic globalization and therefore we confess before God and one another.

(World Alliance Reformed Churches 2004:172)

I am aware of the voices that are contesting the views of the Accra Confession'; however, my point is to illustrate that

6.For more on the argument on redefining the contours of the liberation symbol from a Black Theological perspective without necessarily changing the essence and the goals of Black theology of liberation see Vellem (2007).

7. The word 'blow' is used metaphorically in line with the imagery of the vuvuzela that has been used in this article. It should be read to imply the voicing of our views. The propulsion of the voice is the thought that is intended here. Perhaps the use of the word 'blow' is much more appropriate to signify voices that are crying out. Kairotic voices are propelled in a hostile environment in the same manner as a vuvuzela is blown in hostile conditions, at least in the light of the altercations around its use to which I have already referred.

8.In the same manner, the image of blowing a vuvuzela is used to denote a voice made to be heard.

9.I was fortunate to be a participant in Ghana at the General Council of the World
Prophetic Theology can still be appropriate today in the crisis of ecological degradation.

The expansion of the boundaries of theology that liberation theologies offered, as exemplified in the formation of the $K D$, offers a valuable methodological resource for a dialogue between worldviews, paradigms and models to enrich our democratic ethos. Prophetic Theology, therefore, cannot be equated only to a polemical mode of voicing concerns, but also to a dialogical mode with others, in favour of the oppressed. This theology implies not only the correctness of our messages, adverts, media statements, but also what we do with others in open society to give witness to our commitment to the praxis of faith among the poor. Prophetic ministry is thus a participation in the policymaking processes that are informed and shaped by the voices and narratives of the poor who constitute our primary interlocution of Prophetic Theology. To remind the powers that dominate and undermine the interest of the poor is a constant compulsion for the witness of the church and our hope inspired by the alluring vision of an alternative community founded by Jesus who is the Lord of history. Kairos theology is now an international phenomenon. The recent publication of the $K D$ by the Palestinian Christians is an indication of the intercontinental influence of Kairos theology from South Africa. Indeed, the South African Council of Churches recently adopted a resolution to support this process in Palestine. ${ }^{10}$

\section{CONCLUSION}

I have argued, firstly, that the $K D$ dismisses State and Church theologies in favour of a Prophetic Theology. The $K D$ is thus liberation theology, as I have shown, but how does it link up with the Black Theology of liberation? I have argued that this link is excavated by digging into the streams of prophetic presence in Black Theology through the 'Protest' and 'Confessing Models'. By showing how the contours of confession as 'correct articulation' are inadequate, confession as praxis is central to integrating the design of Kairos theology and the Black Theology of liberation. The compulsion to live out faith in public, beyond the confines of church structures is prophetic. The Black Theology of liberation is thus prophetic as it lends political praxis as an ingredient of confession, the compulsion to give witness in public especially in times of crisis and from the underside of history.

The creative link between Black Theology, Prophetic Theology and the $K D$ is the liberation soil in which they are all rooted. If confession is the source of most inspirations of prophetic witness, then confession as political praxis is what this link is all about. Prophetic Theology is not a guest in public life, but a participant compelled to give witness to the blood of many on the underside of history, the suffering masses who must confirm, participate and confess to the substantive promises of our democracy as we South Africans constantly cry to them: Vumani $-B o !^{11}$

\footnotetext{
(Footnote 9 cont...)

Alliance of Reformed Churches in 2004. The debate about whether the Accra Confession was a 'confession' or not is memorable. For some the Accra confession did not fulfill the traditional requirements of what a confession in orthodox Reformed theology is. This debate went beyond the General Council and I will mention only two publications that capture this debate: The church and economic globalization (2007) and Boesak \& Hansen 2009. Globalisation: The politics of empire, justice and the life of faith. My point is that the Accra Confession is an example of a prophetic voice in our new situation of the globalising world today

10.See the resolutions of the Central Committee of the South African Council of Churches, as formalised in Kempton Park on 09-10 March 2010.

11.The deep imagery of this concluding sentence is inspired by a common practice of ancestor veneration among Africans. The meaning I seek to convey in this symbol is that the veneration of the experience of the masses, that is, those who are on the underside of history, is indispensable for the development of Prophetic Theology and the democratization of our country. The expression often used by sangomas is 'vumani bo' is 'vumani bo' which means a con etween the sangoma and those in consultation. When the sangoma says 'vumani bo' the response is siya vuma!
} 


\section{REFERENCES}

Batista, I., 1995, “'Kairos" as an affirmation of faith', in T. Dladla (ed.), Kairos'95: At the threshold of Jubilee - A conference report, pp. 33-43, The Institute for Contextual Theology, Johannesburg.

Boesak, A., 2004, 'Truth crushed to earth will rise again: Christian theology in South Africa - Looking back', in E. Conradie (ed.), African Christian theologies in transformation, pp. 9-30, Ecumenical Foundation of Southern Africa, Stellenbosch.

Boesak, A.\&Hansen,L.,2009, Globalisation: the politics ofempire,justice and the life of faith, Sun Press, Stellenbosch.

Cone, J.H., 1982, My soul looks back, Abingdon, Nashville.

De Gruchy, J.W., 1991, Liberating reformed theology, William B. Eerdmans, Grand Rapids.

Kalu, O.U., 2006, 'James Cone's legacy in Africa: Confession as a political praxis in the Kairos Document', Verbum et Ecclcesia 27(2), 576-592.

Khabela, G., 1991, 'A seamless garment: Tutu's understanding of the role of the church in South Africa', PhD thesis, Department of Systematic Theology, Union Theological Seminary.

Mosala, J.I., 1989, Biblical hermeneutics and Black Theology in South Africa, William B. Eerdmans, Grand Rapids.

Nolan, A., 1988, God in South Africa: The challenge of the gospel, David Philip, Cape Town.
The Kairos Document: Challenge to the Church: a Theological Comment on the Political Crisis in South Africa, 1995, viewed 24 October 2009, from http://www.sahistory.org.za/pages/ library-resources/official\%20docs/kairos-document.htm

The Kairos Document: Challenge to the Church: a Theological Comment on the Political Crisis in South Africa, 1986, 2nd edn., William B. Eeerdmans, Grand Rapids.

The Chuch and economic globalisation, 2007, The commission of international affairs, Church of Norawy Council on Ecumenical Relations, Norway.

Van der Water, D., 1998, 'The legacy of a prophetic moment: A socio-theological study of the reception and response to the Kairos document amongst churches, faith communities and ecumenical community, focussing on the English-speaking churches in South Africa with special reference to the United Congregational Church of Southern Africa', PhD thesis, School of Theology and Religion, University of Natal.

Vellem, V., 2007, 'The symbol of liberation in South African public life: A Black theological perspective', PhD thesis, Department of Systematic Theology and Ethics, University of Pretoria.

World Alliance Reformed Churches (WARC), 2004, 'Covenanting for justice: The Accra Confession', Reformed World 54(3-4), 169-174.

West, C., 1993, 'Black Theology of liberation as a critique of capitalist civilization', in J.H. Cone \& G. Wilmore (eds.) Black Theology, a documentary history volume two: 1980-1992, pp. 410-425, Orbis, New York. 